\title{
PERBANDINGAN PERFORMANSI SISTEM MC-SS MIMO DENGAN OFDM MIMO
}

\author{
N.P.E.A. Yuniari ${ }^{1}$, N.M.A.E.D. Wirastuti ${ }^{2}$, I.G.A.K.D.D. Hartawan ${ }^{3}$
}

\begin{abstract}
The combination of the system has been doing to improve the reliability of wireless communication. One parameter that indicates the reliability of wireless communication is to reduce the value of BER. The 4G technology uses OFDM transmission technique combined with MIMO antenna technique. Other than that, the combination between transmission technique can also be done, by incorporating the concept of multicarrier OFDM and spread spectrum as known as multicarrier spread spectrum (MC-SS). The combination of OFDM, spread spectrum, and MIMO are supported by the advantages of each of these techniques is expected to give a good performance in supporting the reliability of wireless communication. This research aimed to compare the value of BER vs. Eb/No between MC-SS MIMO system and OFDM MIMO system. The test of these systems are conducted by simulation using MatLab 2012 which aims to provide an overview of other related technologies are capable of providing wireless communication reliability. The results of the simulation shows that the value of BER on MC-SS MIMO system is lower than MIMO OFDM system for all Eb/No. This condition also applies to AWGN and Rayleigh Fading channel.
\end{abstract}

Intisari- Kombinasi sistem dilakukan untuk meningkatkan kehandalan komunikasi wireless. Salah satu parameter yang menunjukkan kehandalan komunikasi wireless adalah dengan mengurangi nilai BER. Pada teknologi 4G menggunakan kombinasi teknik transmisi OFDM dengan teknik antena MIMO. Selain daripada itu, kombinasi antar teknik transmisi juga dapat dilakukan, yaitu dengan menggabungkan konsep multicarrier OFDM dengan spread spectrum yang selanjutnya dikenal dengan multicarrier spread spectrum (MC-SS). Kombinasi antara OFDM, spread spectrum, dan MIMO yang didukung oleh kelebihan dari masing-masing teknik tersebut diharapkan mampu memberikan performansi yang baik dalam mendukung kehandalan komunikasi wireless. Dalam paper ini akan dibandingkan performansi menurut BER vs. Eb/No dari sistem MC-SS MIMO dengan OFDM MIMO.

${ }^{I}$ Mahasiswa Teknik Elektro dan Komputer Fakultas Teknik Universitas Udayana, Kampus Bukit Jimbaran, Badung Bali. 80361, Tel. 0361703315 fax. 0361703315;

email : ekaapsari97@gmail.com

${ }^{2}$ Dosen Teknik Elektro dan Komputer Fakultas Teknik Universitas Udayana, Kampus Bukit Jimbaran, Badung Bali. 80361, Tel. 0361703315 fax. 0361703315 ;

email : dewi.wirastuti@ee.unud.ac.id

${ }^{3}$ Dosen Teknik Elektro dan Komputer Fakultas Teknik Universitas Udayana, Kampus Bukit Jimbaran, Badung Bali. 80361, Tel. 0361703315 fax. 0361703315 ;

email :igak.diafari@ee.unud.ac.id
Pengujian ini dilakukan dengan simulasi menggunakan perangkat lunak MatLab yang bertujuan untuk memberikan gambaran terkait teknologi lain yang mampu memberikan kehandalan komunikasi wireless. Dalam hasil simulasi didapatkan bahwa nilai BER pada sistem MC-SS MIMO lebih rendah dibandingkan dengan sistem

OFDM MIMO untuk semua nilai Eb/No baik pada kanal AWGN maupun Rayleigh Fading.

Kata Kunci- BER, Eb/No, Kehandalan, MIMO, OFDM, spread spectrum

\section{PENDAHULUAN}

Teknologi untuk jaringan wireless kian berkembang. Misalnya, pada mobile communication generasi keempat (4G), jaringan wireless mengadopsi kombinasi sistem antara teknik transmisi OFDM (Orthogonal Frequency Division Multiplexing) dengan teknik MIMO (Multiple Input Multiple Output). Tujuannya adalah untuk meningkatkan data rate dan terlebih lagi adalah mengatasi efek fading dari kanal sehingga kehandalan komunikasi wireless tercapai.

Kombinasi antar teknik transmisi juga dapat dilakukan untuk meningkatkan kehandalan komunikasi wireless. Sejak tahun 1993, telah diperkenalkan kombinasi antara teknik transmisi spread spectrum dengan multi carrier yang selanjutnya dikenal dengan MC-SS [1]. Multi carrier sendiri merupakan konsep dari teknik transmisi OFDM [2].

Masing-masing teknik transmisi OFDM dan spread spectrum memiliki kelebihan. Teknik transmisi OFDM dapat mengatasi efek ISI (Inter Symbol Interference) serta memiliki datarate yang tinggi [3]. Teknik transmisi spread spectrum memiliki kekebalan terhadap distorsi multipath, perencanaan frekuensi yang sederhana, fleksibelitas tinggi, dan tahan terhadap interferensi [1].

Teknik MIMO juga mampu mengatasi masalah gangguan multipath fading pada jaringan wireless. Teknik ini menggunakan beberapa antena pengirim dan penerima yang bertujuan untuk menjadikan sinyal pantulan sebagai penguat sinyal utama sehingga saling mendukung [3].

Dengan kelebihan yang dimiliki oleh masing-masing teknik OFDM, spread spectrum dan MIMO, untuk itu dilakukan kombinasi ketiga teknik tersebut menjadi sistem MC-SS MIMO. Kombinasi sistem MC-SS MIMO perlu diuji kehandalan performansinya melalui perbandingan dengan kombinasi sistem yang sudah ada yaitu OFDM MIMO. Penilaian performansi kedua sistem tersebut selanjutnya ditentukan dengan nilai BER (Bit Error Rate) berbanding Eb/No (Energy per Bit to Noise Power Spectral Density Ratio) 


\section{A. OFDM}

\section{TINJAUAN PUSTAKA}

OFDM adalah bentuk khusus dari multicarrier modulation yang membagi aliran data dengan kecepatan tinggi ke dalam sejumlah aliran data kecepatan rendah kemudian dikirimkan melalui beberapa subcarrier. Pada OFDM, data masukan dialirkan ke beberapa subcarrier paralel yang saling orthogonal dengan laju data yang lebih rendah. Subcarrier tidak ditempatkan berdasarkan bandwidth yang ada, tetapi disusun untuk saling overlapping dan diatur jarak antara subcarrier agar memiliki sifat yang orthogonal [4]. Sistem OFDM sederhana ditunjukkan pada blok diagram Gambar 1:

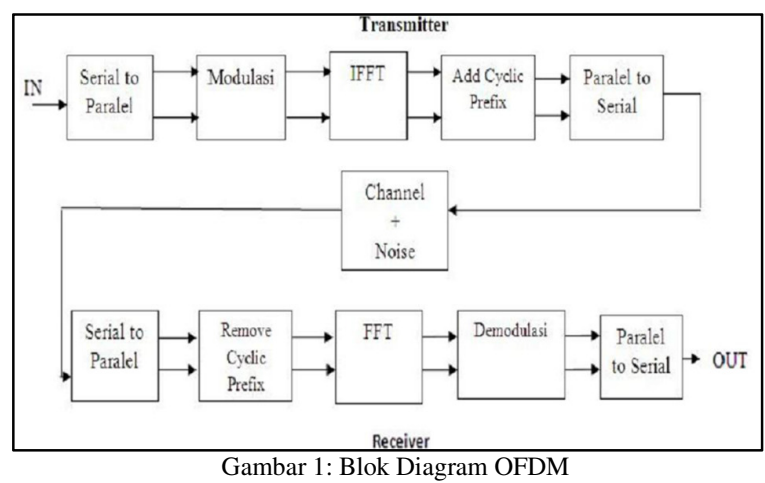

B. Spread Spectrum

Proses direct sequence spread spectrum ditunjukkan pada blok diagram 2:

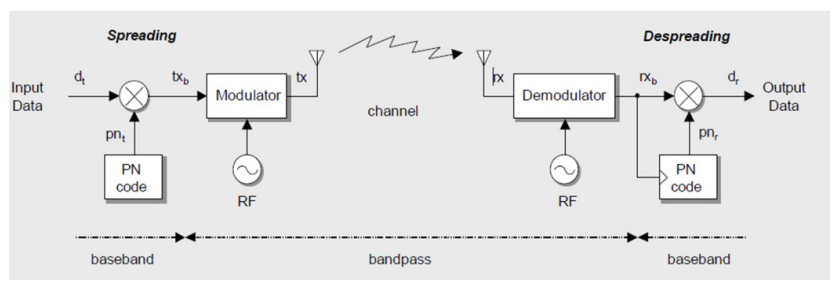

Gambar 2: Blok Diagram Direct Sequence Spread Spectrum

Keterangan dari building block sistem DSSS pada Gambar 2 tersebut adalah sebagai berikut.

1) Input: Binary data $\mathrm{d}_{\mathrm{t}}$ dengan symbol rate $\mathrm{R}_{\mathrm{s}}=1 / \mathrm{T}_{\mathrm{s}}$ (=bitrate $\mathrm{R}_{\mathrm{b}}$ untuk BPSK). Pseudo-noise code $\mathrm{pn}_{\mathrm{t}}$ dengan chip rate $\mathrm{R}_{\mathrm{c}}=1 / \mathrm{T}_{\mathrm{c}}$ [5].

2) Spreading: Pada transmitter (txb), binary data $\left(\mathrm{d}_{\mathrm{t}}\right)$ (untuk BPSK, I dan Q untuk QPSK) secara langsung dikalikan dengan PN sequence $\left(\mathrm{pn}_{\mathrm{t}}\right)$ yang terpisah dari baseband yang binary data, untuk memproduksi sinyal baseband yang ditransmisikan $\mathrm{tx}_{\mathrm{b}}$ [5]. Proses perkalian tersebut mengacu pada (1).

$$
\mathrm{txb}=\mathrm{dt} \cdot \mathrm{pn}_{\mathrm{t}}
$$

Efek dari perkalian dt dengan PN sequence adalah untuk menyebarkan baseband bandwidth $\mathrm{R}_{\mathrm{b}}$ dari $\mathrm{d}_{\mathrm{t}}$ ke baseband bandwidth $\mathrm{R}_{\mathrm{c}}$ [5].

3) Despreading: Sinyal Spread Spectrum tidak bias dideteksi dengan penerima narrowband konvensional. Pada receiver, sinyal baseband rxb yang diterima dikalikan dengan $\mathrm{PN}$ sequence $\mathrm{pn}_{\mathrm{t}}[5]$

Jika $\mathrm{pn}_{\mathrm{r}}=\mathrm{pn}_{\mathrm{t}}$ dan disinkronisasi ke PN sequence pada data yang diterima, kemudian binary data yang dipulihkan diproduksi pada $\mathrm{d}_{\mathrm{r}}$ akibat perkalian dari sinyal spread spectrum $\mathrm{rx}_{\mathrm{b}}$ dengan $\mathrm{PN}$ sequence $\mathrm{pn}_{\mathrm{t}}$ digunakan pada transmitter adalah untuk despread bandwidth $\mathrm{rx}_{\mathrm{b}}$ ke Rs [5].

Jika $\mathrm{pn}_{\mathrm{r}} \neq \mathrm{pn}_{\mathrm{t}}$, kemudian tidak terjadi despread. Sinyal $\mathrm{d}_{\mathrm{r}}$ memiliki spread spectrum. Penerima tidak mengetahui PN sequence dari transmitter sehingga tidak bisa memproduksi kembali data yang telah dikirim [5].

\section{Walsh-Hadamard Code}

Kode Hadamard-Walsh dibangkitkan dalam aturan kode $\mathrm{N}$ $=2^{\mathrm{n}}$ dengan panjang $\mathrm{N}=2^{\mathrm{n}}$. Pembangkitan code ini memiliki algoritma yang sangat sederhana [5] yaitu mengacu pada (2),

$$
H_{2}=\left[\begin{array}{cc}
H_{N / 2} & H_{N / 2} \\
H_{N / 2} & -H_{N / 2}
\end{array}\right]
$$

dengan $\mathrm{H}_{1}=[1]$

Baris atau kolom dari matriks $\mathrm{H}_{\mathrm{N}}$ adalah kode HadamardWalsh seperti yang ditunjukkan berikut ini [5].

$$
H_{2}=\left[\begin{array}{cc}
1 & 1 \\
1 & -1
\end{array}\right] \quad H_{4}=\left[\begin{array}{rrrr}
1 & 1 & 1 & 1 \\
1 & -1 & 1 & -1 \\
1 & 1 & -1 & -1 \\
1 & -1 & -1 & 1
\end{array}\right]
$$

\section{MIMO}

Prinsip kerja MIMO adalah memperbanyak sinyal informasi yang dipancarkan untuk meningkatkan kemampuan komunikasi dan mengurangi error yang dapat terjadi akibat kanal transmisi [4].

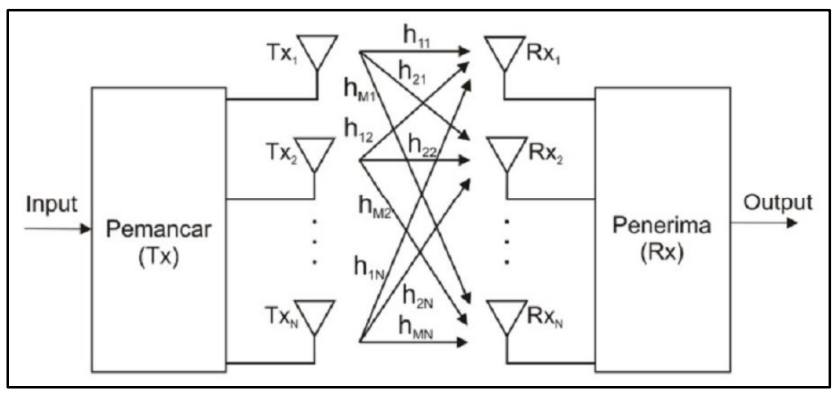

Gambar 3: Skema Antena MIMO

Persamaan 3 merupakan representasi dari sistem MIMO [4] yang ditunjukkan pada Gambar 3,

$$
\mathrm{y}=\mathrm{h} . \mathrm{x}+\mathrm{n}
$$

dimana, y merupakan vektor sinyal yang diterima, $h$ merupakan matrix respon impuls kanal dari $\mathrm{N}$ jumlah antena pemancar dan $\mathrm{M}$ jumlah antena penerima $(\mathrm{NxM})$, $\mathrm{s}$ menyatakan vektor sinyal yang ditransmisikan, dan $n$ menyatakan vektor noise AWGN [4].

\section{E. Space Time Block Code}

Sistem STBC ini akan mengirimkan dua simbol yang berbeda secara bersamaan. Pada saat waktu t, antena pertama 
(Tx1) akan mengirimkan sinyal S0 dan antena kedua (Tx2) mengirimkan sinyal S1. Diasumsikan bahwa S0 dan S1 merupakan simbol yang telah dimodulasi. Kemudian pada saat waktu $\mathrm{t}+\mathrm{T}$, simbol dari masing-masing antena pemancar dikonjugat sehingga pada antena pertama (Tx0) akan mengirimkan sinyal - dan pada antena (Tx1) mengirimkan sinyal $+[4]$ seperti yang ditunjukkan Gambar 4:

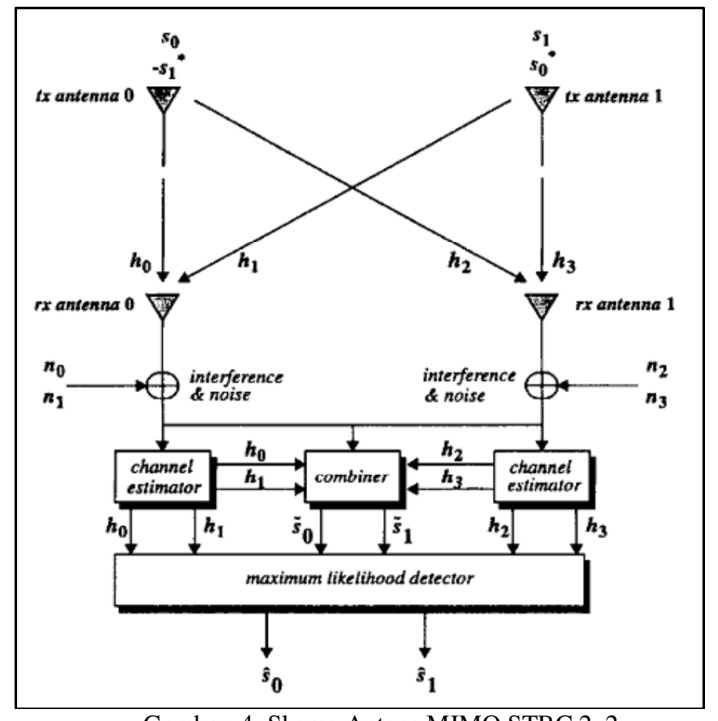

Gambar 4: Skema Antena MIMO STBC 2x2

\section{F. Modulasi Quadrature Phase Shift Keying}

QPSK merupakan teknik pengkodean M-ary dimana $\mathrm{M}=$ 4 (quaternary). Dalam modulasi QPSK terdapat empat fase keluaran dari sinyal pembawa untuk menyatakan empat simbol. Satu simbol QPSK terdiri dari 2 buah bit yaitu "00", "01", "10", dan "11". Setiap satu simbol akan mengalami perubahan fasa sebesar $90^{\circ}(\pi / 2)$ [4].

Pada Gambar 5 dapat dilihat untuk konstelasi 00, pada Re channel $(\mathrm{I})=+1$ dan Im channel $(\mathrm{Q})=+1$. Untuk konstelasi 01, $\operatorname{Re}(\mathrm{I})=-1$, dan $\operatorname{Im}(\mathrm{Q})=+1$. Untuk konstelasi 11, untuk saluran $\operatorname{Re}(\mathrm{I})=-1$ dan $\operatorname{Im}(\mathrm{Q})=-1$. Untuk konstelasi 10 , untuk $\operatorname{Re}(\mathrm{I})=+1$ dan $\operatorname{Im}(\mathrm{Q})=-1$. Setiap nilai konstelasi 1 dan -1 disimbolkan dengan 0.7071 dan -0.7071 [5].

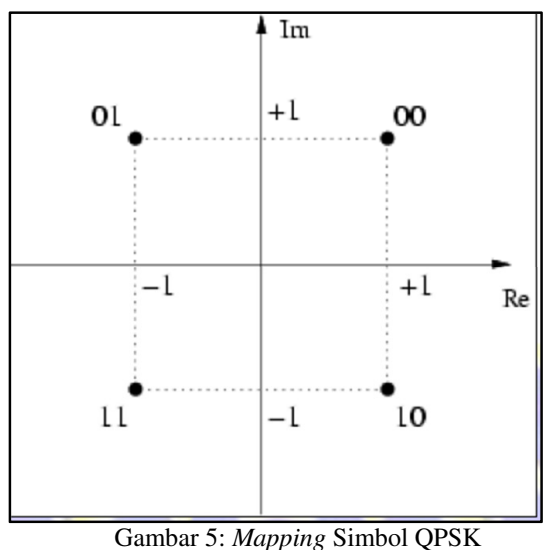

N.P.E.A.Yuniari: Perbandingan Performansi Sistem MC-SS.....

\section{G. Additive White Gaussian Noise}

AWGN (Additive White Gaussian Noise) mempunyai karakteristik respon frekuensi yang sama disepanjang frekuensi dan variannya sama dengan satu. Pada kanal transmisi selalu terdapat penambahan noise yang timbul karena akumulasi noise termal dari perangkat pemancar, kanal transmisi, dan perangkat penerima. AWGN merupakan model kanal sederhana dan umum dalam suatu sistem komunikasi [5]. Model kanal ini dapat digambarkan seperti Gambar 6:

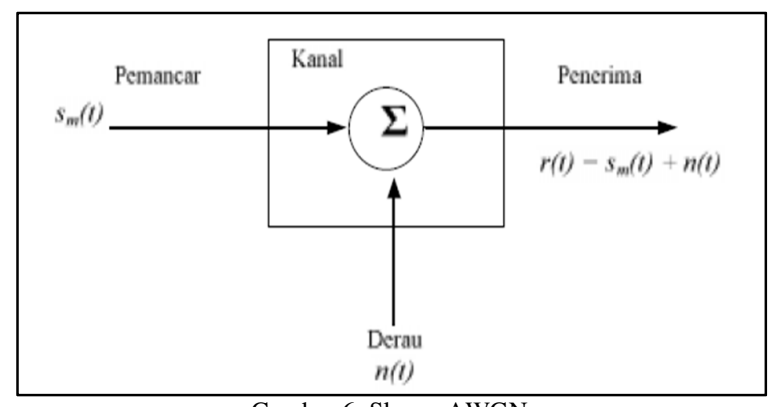

Gambar 6: Skema AWGN

\section{H. Kanal Flat Fading}

Flat Fading (Fading Rata) disebut juga Rayleigh Fading dapat terjadi apabila kanal mempunyai penguatan yang konstan dan tanggapan fase linier dengan bandwidth yang lebih lebar dibandingkan dengan bandwidth sinyal yang ditransmisikan. Pada kondisi ini, level sinyal yang diterima berubah terhadap waktu yang disebabkan oleh multipath [5]. Karakteristik kanal flat fading ditunjukkan pada Gambar 7:

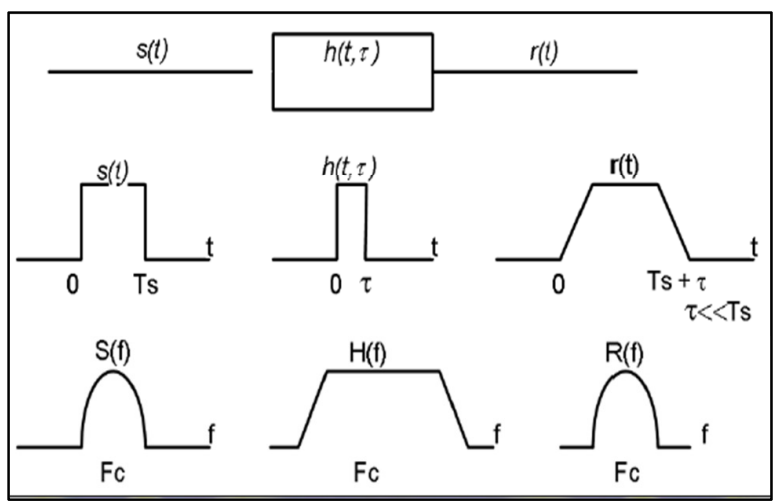

Gambar 7: Skema Kanal Rayleigh Fading

I. BER

Dalam telekomunikasi, rasio error adalah rasio jumlah bit, elemen, karakter, atau blok yang diterima dengan salah dibanding jumlah total bit, elemen, karakter, ataupun blok yang dikirim sepanjang interval waktu tertentu. Rasio yang paling sering ditemui adalah bit error ratio (BER). Contoh BER adalah jumlah kesalahan bit yang diterima dibagi dengan jumlah total bit yang dikirimkan. Biasanya kurva BER digambarkan dalam hubungan BER (dB) dengan SNR (dB) atau BER (dB) dengan $E$ b/No (dB) [6]. 


\section{J. $E b / N o$}

$\mathrm{Eb} / \mathrm{No}$ adalah parameter yang biasa digunakan dalam komunikasi digital. Hal ini sangat berguna saat membandingkan performa bit error rate (BER) untuk modulasi digital yang berbeda-beda tanpa menyertakan parameter pita frekuensi. Parameter lain yang sering digunakan adalah Es/NO (energy per symbol to noise power spectral density ratio) [5].

\section{METODE PENELITIAN}

\section{A. Pemodelan Sistem MC-SS MIMO}

Pemodelan sistem MC-SS MIMO ditunjukkan pada blok diagram, seperti yang ditunjukkan pada Gambar 8:

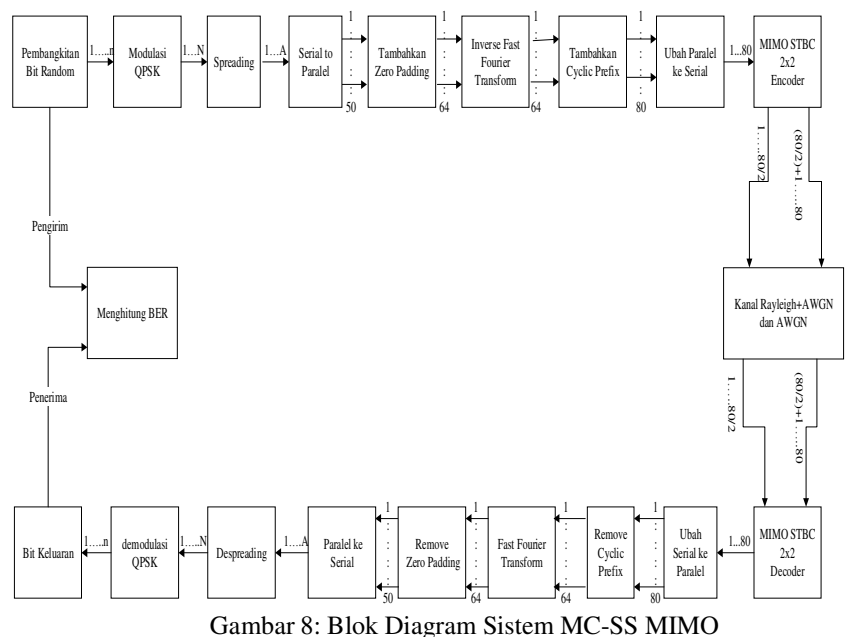

Berdasarkan pada Gambar 8, pada pemancar MC-SS terdapat beberapa blok tahapan, dimulai dari blok modulasi QPSK yang membagi bit inputan (jika $\mathrm{n}=100.000$ ) ke dalam konstelasi I dan Q. Sehingga yang awalnya ada jumlah bit dari 1 sampai $n$ akan menghasilkan jumlah simbol sebanyak $n / 2$ simbol yang kemudian dinotasikan dengan 1 sampai dengan $\mathrm{N}$ $(\mathrm{N}=\mathrm{n} / 2)$. Proses spread spectrum yang digunakan berupa direct sequence spread spectrum. Dalam blok spreading, ada dua hal yang mempengaruhi, yaitu spreading code dan spreading factor. Data hasil modulasi yang mengalami proses spreading mengubah jumlah baris, dimana jumlah baris hasil spreading menyesuaikan pada nilai variable spreading factor. Notasi A merupakan hasil perkalian antara $\mathrm{N}$ dan panjang variable spreading factor.

Kemudian simbol yang telah di spreading diubah dari deretan serial ke parallel dengan jumlah barisnya adalah 50 baris dalam satu kolom disesuaikan dengan jumlah subcarrier OFDM. Dalam paper ini, subcarrier yang digunakan dalam simulasi untuk satu simbol OFDM adalah 50 subcarrier. Pada proses serial to parallel ini adalah bentuk menumpangkan informasi pada beberapa subcarrier. Tiap satu kolom yang terdiri atas 50 baris dalam matriks hasil perubahan serial to parallel merupakan satu simbol OFDM. Dalam Gambar 8 aliran data parallel yang ditampilkan hanya untuk satu simbol OFDM. Penambahan zero padding berupa menambahkan bit 0 sebanyak 14 deret pada deretan data parallel agar sesuai dengan jumlah simbol FFT (FFT size 64).

Kemudian pada blok Inverse Fast Fourier Transfrom (IFFT) bertujuan untuk mengubah aliran simbol dari domain frekuensi ke domain waktu. Ukuran IFFT ini adalah 64, sudah sesuai dengan aliran simbol yang memiliki 64 baris dan dalam bentuk aliran data parallel. Tahapan selanjutnya adalah penambahan guard interval (GI) berupa cyclic prefix (CP). Panjang cyclic prefix yang digunakan sebesar 16 baris sehingga panjang simbol OFDM akan berubah dari 1 sampai ke 80. Selanjutnya sebelum masuk ke MIMO, simbol OFDM di ubah dari parallel ke serial terlebih dahulu. Pada sisi MIMO STBC 2x2 aliran data dibagi menjadi dua bagian untuk dikirimkan pada dua antena yang berbeda. Pada sisi penerima dilakukan hal yang berkebalikan dengan sisi pengirim. Kanal yang digunakan dalam sistem ini adalah AWGN dan Rayleigh.

\section{B. Pemodelan Sistem OFDM MIMO}

Pemodelan sistem OFDM MIMO ditunjukkan pada blok diagram, seperti yang ditunjukkan pada Gambar 9:

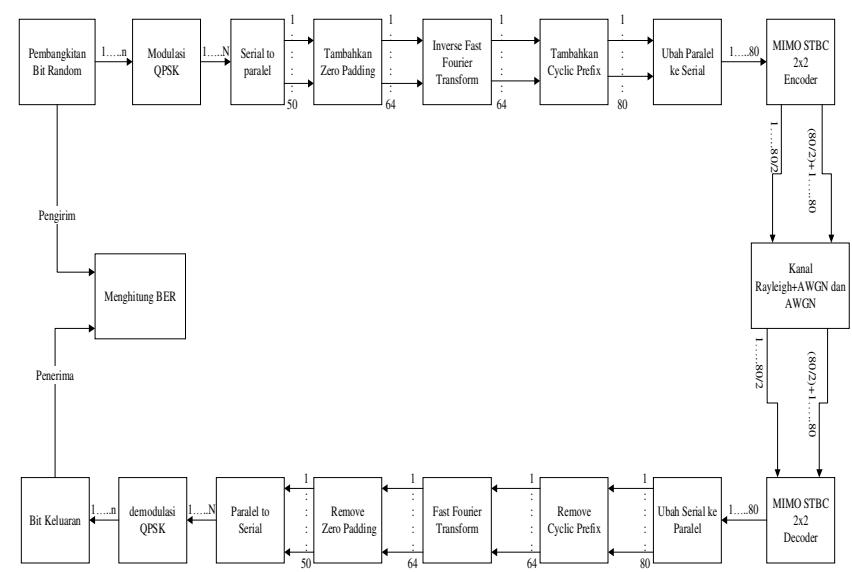

Gambar 9: Blok Diagram Sistem OFDM MIMO

Proses pada sistem OFDM-MIMO hampir sama dengan sistem MC-SS MIMO hanya saja tidak terdapat proses spreading simbol dalam sistem OFDM MIMO pada blok setelah modulasi QPSK. Simbol hasil modulasi pada sistem OFDM MIMO setelah dimodulasi kemudian diubah dari deretan serial ke parallel untuk menyesuaikan dengan subcarrier. Tahapan selanjutnya adalah penambahan zero padding, IFFT, penambahan cyclic prefix, kemudian diubah kembali dari parallel ke serial sebelum masuk ke blok MIMO STBC $2 \times 2$.

\section{HASIL DAN PEMBAHASAN}

Simulasi sistem MC-SS MIMO dan OFDM MIMO menggunakan perangkat lunak MatLab 2012a. Simulasi dikerjakan sesuai dengan pemodelan pada Gambar 8 dan 9 . Parameter yang digunakan dalam simulasi kedua tersebut ditunjukkan dengan Tabel 1: 
TABEL 1: PARAMETER SIMULASI SISTEM MC-SS MIMO DAN OFDM MIMO

\begin{tabular}{|l|c|}
\hline \multicolumn{1}{|c|}{ Parameter } & Nilai yang digunakan \\
\hline Panjang satu simbol OFDM & 64 \\
\hline Jumlah subcarrier & 52 \\
\hline Jumlah simbol FFT & 64 \\
\hline Tipe modulasi & QPSK \\
\hline Panjang Zero Padding & 14 \\
\hline Guard interval type & Cyclic prefix \\
\hline Panjang cyclic prefix & 16 \\
\hline Jenis spreading code & Walsh-Hadamard \\
\hline Variabel spreading factor & 4 \\
\hline Jenis spread spectrum & Direct sequence spread \\
\hline User type & spectrum \\
\hline MIMO type & STBCe user \\
\hline Nilai Eb/No & -10 sampai 10 \\
\hline Jumlah bit yang input & 100.000 bit (random) \\
\hline
\end{tabular}

Hasil simulasi sistem MC-SS MIMO ditunjukkan pada Gambar 10 sedangkan hasil simulasi sistem OFDM MIMO ditunjukkan pada Gambar 11:

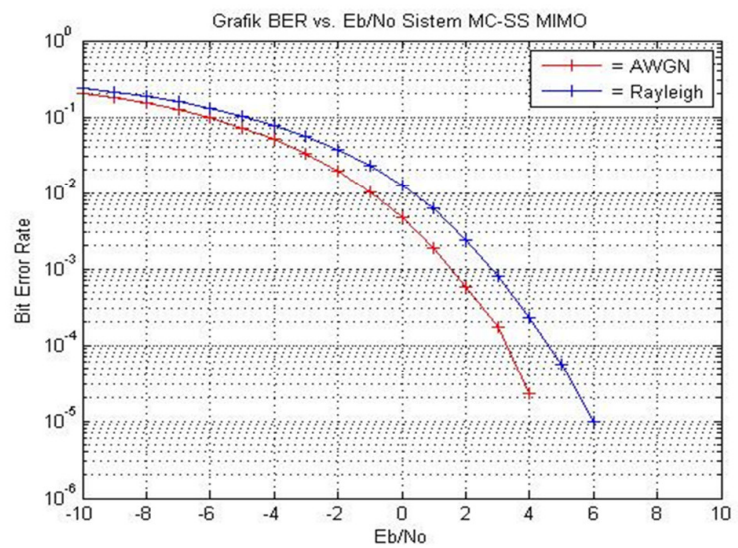

Gambar 10: Grafik BER vs. Eb/No Sistem MC-SS MIMO

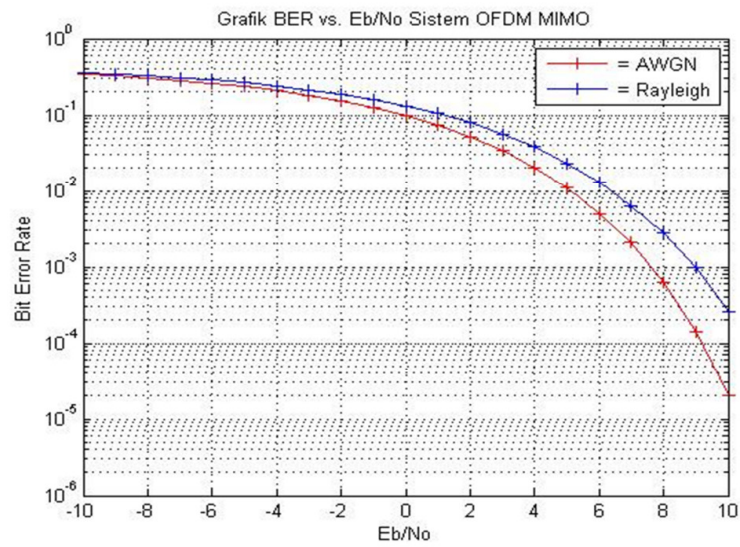

Gambar 11: Grafik BER vs. Eb/No Sistem OFDM MIMO
Melalui kedua gambar tersebut dapat dilihat bahwa performansi BER vs. Eb/No sistem MC-SS MIMO dan OFDM MIMO pada kanal AWGN lebih baik dibandingkan dengan Rayleigh. Hal ini dikarenakan pada kanal AWGN hanya terdapat penambahan noise pada bit yang ditransmisikan sedangkan pada kanal Rayleigh bit yang ditransmisikan selain ditambahkan noise juga mengalami efek fading. Selain itu, nilai BER akan semakin berkurang seiring dengan meningkatnya nilai Eb/No pada kondisi noise yang sama baik untuk sistem MC-SS MIMO dan OFDM MIMO.

Perbandingan sistem MC-SS MIMO dengan OFDM MIMO ditunjukkan dengan Gambar 12 untuk kanal AWGN dan Gambar 13 untuk kanal Rayleigh.

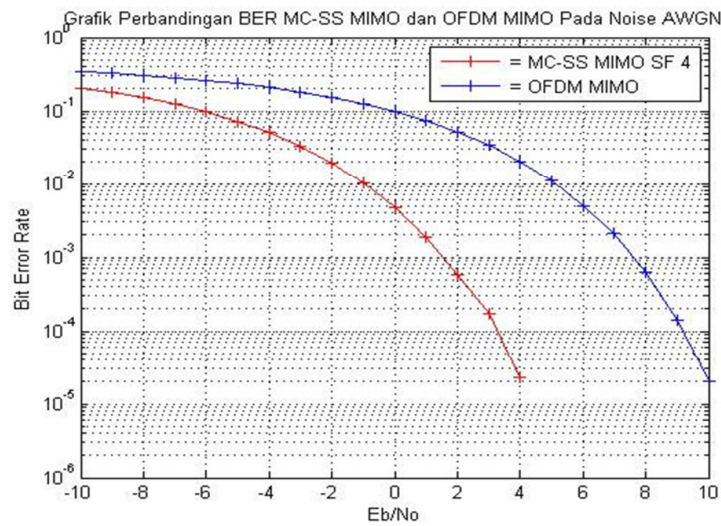

Gambar 12: Grafik BER vs. Eb/No untuk Perbandingan Sistem MC-SS MIMO dengan OFDM MIMO pada Kanal AWGN

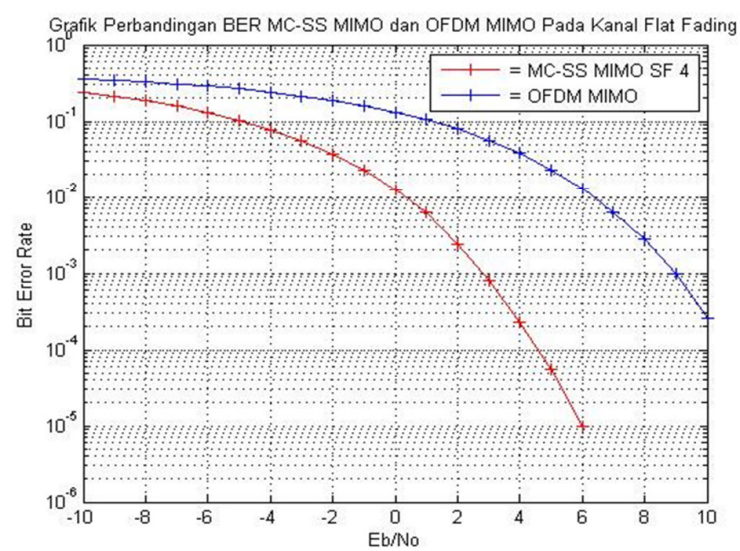

Gambar 13: Grafik BER vs. Eb/No untuk Perbandingan Sistem MC-SS MIMO dengan OFDM MIMO pada Kanal Rayleigh Fading

Berdasarkan Gambar 12 dan 13 dapat dilihat bahwa sistem MC-SS MIMO memiliki performansi BER vs. Eb/No yang lebih baik dibandingkan dengan sistem OFDM MIMO. Hal ini dikarenakan pada sistem OFDM MIMO tidak terdapat proses spreading seperti pada sistem MC-SS MIMO. Proses spreading berupa mengalikan bit yang akan ditransmisikan dengan sejumlah chips yang dibangkitkan dengan spreading

N.P.E.A.Yuniari: Perbandingan Performansi Sistem MC-SS.... 
code. Jumlah chips yang dibangkitkan oleh spreading code dipengaruhi oleh nilai spreading factor.

Dalam paper ini spreading factor atau jumlah chips yang dibangkitkan untuk sistem MC-SS MIMO adalah empat. Satu bit yang akan ditransmisikan kemudian dilipatgandakan menjadi empat simbol. Maka dari itu dalam sistem MC-SS MIMO terdapat cadangan dari bit yang ditransmisikan. Sehingga jumlah simbol yang ditransmisikan oleh sistem MCSS MIMO lebih banyak dibandingkan dengan sistem OFDM MIMO. Ketika pada kondisi noise dan fading yang sama untuk sistem MC-SS MIMO dan OFDM MIMO menyebabkan sejumlah simbol mengalami kerusakan sehingga tidak bisa dideteksi kembali, pada sistem MC-SS MIMO simbol masih memungkinkan untuk dideteksi kembali karena ada cadangan simbol tersebut. Sedangkan pada OFDM MIMO yang satu bitnya direpresentasikan dalam satu simbol, ketika simbol mengalami kerusakan dan tidak bisa dideteksi kembali, maka data (bit) tersebut akan hilang.

V. SIMPULAN
Berdasarkan pada hasil dan pembahasan dapat

1) Performansi sistem MC-SS MMO dan OFDM MIMO ditinjau pada kanal AWGN dan rayleigh fading dimana kanal AWGN memiliki performansi BER vs. Eb/No yang paling baik diantara pemodelan kanal lainnya. Hal ini dikarenakan pada pemodelan kanal AWGN, transmisi sinyal tidak dilewatkan pada kanal melainkan hanya penambahan noise AWGN sedangkan pada kanal Rayleigh fading, terjadi efek fading yang menyebabkan BER bertambah buruk.

2) Hasil perbandingan sistem MC-SS MIMO dan OFDM MIMO menunjukkan bahwa sistem MC-SS MIMO memiliki performansi yang lebih baik dibandingkan dengan OFDM MIMO ditinjau dari nilai BER vs. Eb/No yang dihasilkan. Hal ini dikarenakan pada sistem MC-SS MIMO terdapat proses spreading data simbol dengan sejumlah chips yang ditentukan berdasarkan nilai dari spreading factor. Sehingga ketika satu data simbol disebarkan dalam beberapa chips maka akan terdapat cadangan dari data simbol tersebut dengan demikian kesalahan yang terjadi tidak berpengaruh secara signifikan. Sedangkan pada sistem OFDM MIMO yang satu data simbol tidak memiliki cadangan sehingga saat terjadi kesalahan data simbol tersebut sepenuhnya mengalami kesalahan.

\section{REFERENSI}

[1] Fazel, K. and Kaiser, S., Multi-Carrier and Spread Spectrum Systems From OFDM and MC-CDMA to LTE and WiMAX, Second Edition, New York: John Wiley \& Sons, 2008.
[2] Faisal, Muhammad, "Pengaruh Panjang Cyclic Prefix Terhadap Kinerja Sistem OFDM Pada WiMax," ST. Skripsi, Medan: Universitas Sumatra Utara, 2009.

[3] Hakim, M. Lukmanul, Sukiswo, Santoso Imam, "Analisis Kinerja Sistem MIMO OFDM Pada Kanal Rayleigh dan AWGN dengan Modulasi QPSK," ST. Skripsi, Semarang: Universitas Diponegoro, 2010.

[4] Purwanto Teguh Bayu, "Analisis Unjuk Kerja Teknik MIMO STBC dan V-BLAST Pada Sistem Orthogonal Frequency Division Multiplexing," ST. Skripsi, Denpasar: Universitas Udayana, 2015.

[5] Meel, Ir. J., Spread Spectrum, Belgium : Sirius Communications, 1999.

[6] Awirya, Valen dan Sukiswo, "Analisis Kinerja Kombinasi Sistem CDMA-OFDM MIMO," ST. Skripsi, Semarang: Universitas Diponegoro, 2010.

[7] Astawa, I Gede Puja., Hendrantoro, Gamantyo., Suryani, Titiek., Pratiarso, Aries., dan Moegiharto, Yoedy, "Studi Karakteristik dan Kinerja Teknik MIMO-OFDM pada Sistem Komunikasi Wireless untuk Indoor Channel," The 19th Asia Pacific Symposium on Intelligent and Evolutionary Systems, pp. 228-232.

[8] Barros Daniel Jose Fernandes, "Orthogonal Frequency-Division Multiplexing For Optical Communications" M.Eng. Thesis, United States : Standford University, 2011.

[9] Cho, Yong Soo., Kim, Jaekwon., Yang, Won Young., and Kang, Chung-Gu. MIMO-OFDM Wireless Communications With MATLAB, New York : John Wiley \& Sons, 2010.

[10] Kushwah, Mr. Atul Singh, "Manglasheril, Mr. Sachin. Performance Estimation of 2*3 MIMO-MC-CDMA using Convolution Code," International Journal of Computer Trends and Technology, vol. 9 no. 1, Pp. 21-25, 2014.

[11] Nejib, Boubaker., Khaled, Ben Letaief., and Ross, D. Murch, "Performance of BLAST Over Frequency-Selective Wireless Communication Channels," IEEE Trans. Comm., vol. 50, no. 2, pp. 196-199, 2002.

[12] Rachmat, Basuki., Muayadi, Ali., Fahmi., dan Arfianto. "Simulasi Sistem DS-CDMA Dengan Berbagai Kode Penebar." Seminar Nasional Aplikasi Teknologi, 2007, Pp. C-1 - C-7.

[13] Shah, Syed M. Zafi S., Umarani, A.W., and Memon, Aftab A., "Performance Comparison of OFDM, MC-CDMA and OFCDM for 4G Wireless Broadband Access and Beyond," Proceedings of Progress In Electromagentic Research Symposium, 2011, Pp. 1396 - 1399.

[14] Sharma, Vishal. and Sharma, Richa., "Analysis of Spread Spectrum in Matlab," International Journal of Scientific \& Engineering Research, vol. 5 issue 1: Pp. 1899-1902, 2014.

[15] Singh, Astha., "Performance Analysis of Spread Spectrum Techniques," Proceedings Of Conference on Advances in Communication and Control Systems 2013, 2013, pp. 683-687.

[16] Sinha, Nirmalendu Bikas., M, Mitra., "Investigating The Impact Of Spectrum Efficient OFDM-MIMO and MC-CDMA-MIMO Communication System For ITS," Journal of Theoretical and Applied Information Technology, vol 19 no. 1 Pp. 1-8, 2010.

[17] Sklar, Bernard., "Rayleigh Fading Channels in Mobile Digital Communication System Part I : Characterization," IEEE Communications Magazine, ISSN : 0163-6804, July. 1997.

[18] Sklar, Bernard., "Rayleigh Fading Channels in Mobile Digital Communication System Part II : Mitigation," IEEE Communications Magazine, ISSN : 0163-6804, July. 1997. 